\title{
Opinion: Prisons that Withhold Menstrual Pads Humiliate Women and Violate Basic Rights
}

\author{
Chandra Bozelko
}

Everyone laughed when Piper Chapman emerged from the shower during the first season of Orange Is the New Black with bootleg shoes made of maxi pads - and inmates do sometimes waste precious resources like sanitary products with off-label uses. ${ }^{1}$ At York Correctional Institution in Niantic, Connecticut, where I spent more than six years, I used the tampons as scouring pads - certainly not as sponges, because prison tampons are essentially waterproof- when I needed to clean a stubborn mess in my cell.

That should not lead anyone to think that sanitary products are easy to come by in jail. At York, each cell, which houses two female inmates, receives five pads per week to split. I'm not sure what they expect us to do with the fifth but this comes out to 10 total for each woman, allowing for only one change a day in an average five-day monthly cycle. The lack of sanitary supplies is so bad in women's prisons that I have seen pads fly right out of an inmate's pants: prison maxi pads don't have wings and they have only average adhesive so, when a woman wears the same pad for several days because she can't find a fresh one, that pad often fails to stick to her underwear and the pad falls out. It's disgusting but it's true.

The only reason I dodged having a maxi pad slither off my leg is that I layered and quilted together about six at a time so I could wear a homemade 
diaper that was too big to slide down my pants. I had enough supplies to do so because I bought my pads from the commissary. However, approximately $80 \%$ of inmates are indigent and cannot afford to pay the $\$ 2.63$ the maxi pads cost per package of 24 , as most earn 75 cents a day and need to buy other necessities like toothpaste ( $\$ 1.50$, or two days' pay) and deodorant $(\$ 1.93$, almost three days' pay). Sometimes I couldn't get the pads because the commissary ran out: they kept them in short supply as it appeared I was the only one buying them.

Connecticut is not alone in being cheap with its supplies for women. Inmates in Michigan filed suit last December alleging that pads and tampons are so scarce that their civil rights have been violated. One woman bled through her uniform and was required to dress herself in her soiled jumpsuit after stripping for a search.

The reasons for keeping supplies for women in prison limited are not purely financial. Even though keeping inmates clean would seem to be in the prison's self-interest, prisons control their wards by keeping sanitation just out of reach. Stains on clothes seep into self-esteem and serve as an indelible reminder of one's powerlessness in prison. Asking for something you need crystallizes the power differential between inmates and guards; the officer can either meet your need or he can refuse you, and there's little you can do to influence his choice.

When the York Correctional Institution became coed during my sentence - merging the old Gates Correctional Institution and the women's prison - a lieutenant who spent his career at York and was unaccustomed to working with male inmates told a group of inmates that the men would rather defecate in their pants than ask him for toilet paper and get jerked around for it.

To ask a macho guard for a tampon is humiliating. But it's more than that: it's an acknowledgement of the fact that, ultimately, the prison controls your cleanliness, your health and your feelings of self-esteem. The request is even more difficult to make when a guard complains that his tax dollars shouldn't have to pay for your supplies. You want to explain to him that he wouldn't have a paycheck to shed those taxes in the first place if prison staff weren't needed to do things like feeding inmates and handing out sanitary supplies but you say nothing because you want that maxi pad.

The guards' reluctance to hand out the supplies is understandable because of inmates' off-label uses for the products. Women use the pads and tampons for a number of things besides their monthly needs: to clean their cells, to make earplugs by ripping out the stuffing, to create makeshift gel pads to insert under their blisters in uncomfortable work boots or to muffle the bang that sounds when a shaky double bed hits a cement wall whenever either of its sleepers move. The staff watches us waste a precious commodity. What they fail to acknowledge is that these alternative uses fill other unfulfilled needs for a woman to maintain her physical and mental health. If we had 
adequate cleaning supplies, proper noise control, band-aids for our blisters or stable beds, we would happily put the pads in our pants.

There are ways to restore dignity to America's inmates. For example, we could remove the entire sanitary supply problem if American prisons bought the newly-released Thinx for female inmates, which are super absorbent, stain-free underwear designed by a woman's start-up. Thinx are expensive \$200 for seven pair - but they still might be cost effective when you factor in the cost of buying disposable pads and the time and energy devoted to the pad power struggle in women's prisons. But I doubt that corrections systems in the United States will give up the forced scarcity of menstrual products in prison.

Though many argue that prisoners cannot be pampered in jail, having access to sanitary pads is not a luxury - it is a basic human right. Just like no-one should have to beg to use the toilet, or be given toilet paper, women too must be able to retain their dignity during their menstrual cycle. Using periods to punish women simply has no place in any American prison.

\section{Note}

1. "Prisons that Withhold Menstrual Pads Humiliate Women and Violate Basic Rights" by Chandra Bozelko was first published on June 12, 2015 in The Guardian. Reprinted with permission. No further reproduction or distribution of the material is allowed without permission from the publisher.

Open Access This chapter is licensed under the terms of the Creative Commons Attribution 4.0 International License (http://creativecommons.org/licenses/ by $/ 4.0 /$ ), which permits use, sharing, adaptation, distribution and reproduction in any medium or format, as long as you give appropriate credit to the original author(s) and the source, provide a link to the Creative Commons license and indicate if changes were made.

The images or other third party material in this chapter are included in the chapter's Creative Commons license, unless indicated otherwise in a credit line to the material. If material is not included in the chapter's Creative Commons license and your intended use is not permitted by statutory regulation or exceeds the permitted use, you will need to obtain permission directly from the copyright holder.

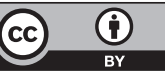

